\title{
DEVELOPMENT OF A NEW TYPE OF WORKER IN THE KNOWLEDGE ECONOMY THEORY Osaul A.O.
}

Zaporizhzhia National University

Ukraine, 69600, Zaporizhzhia, Zhukovsky str., 66

\begin{tabular}{|c|c|}
\hline & ORCID 0000-0002-5194-9799 \\
\hline $\begin{array}{l}\text { Key words: } \\
\text { knowledge, accumulation, intangible } \\
\text { esources, knowledge economy, knowledge } \\
\text { workers, knowledge networking, learning } \\
\text { economy, learning workers. }\end{array}$ & $\begin{array}{l}\text { The concept of a new type of worker in the framework of the knowledge economy } \\
\text { paradigm has been analysed. The evolution of knowledge economy theory in the } \\
21^{\text {st }} \text { century has been illustrated, i.e. it has been demonstrated that the progress in } \\
\text { the new generation of Millennials attitude towards work, social interactions`' } \\
\text { innovation infrastructures, socio-economic, legal and institutional changes cause } \\
\text { the emergence and further development of a specific environment for a new type } \\
\text { of workers activity. The most substantial research works of foreign scholars have } \\
\text { been generalized. The intangible nature of the main productive force of the } \\
\text { economic society, the necessity to generate, accumulate and distribute knowledge } \\
\text { by knowledge and learning workers by means of personal contacts through } \\
\text { knowledge networks have been emphasized. It has been concluded that there is a } \\
\text { number of characteristics, which distinguish manual worker productivity and } \\
\text { knowledge worker productivity. Knowledge workers are task-oriented, seek for } \\
\text { personal responsibility and thus autonomy, associate themselves with continuous } \\
\text { innovations and the most valuable asset of an organization, take part in } \\
\text { simultaneous training and teaching. It has been pointed out that it is impossible to } \\
\text { assess knowledge workers impact on organizational performance applying only } \\
\text { quantitative approach. A new type of workers as problem-solving professionals } \\
\text { opts for a new type of flexible organization which management is ready for } \\
\text { changes. As a perspective which has its reflections right now it has been shown } \\
\text { that modern employees look more for temporary employment and short-term } \\
\text { contracts. It has been revealed that so-called boundaryless careers are perceived as } \\
\text { inter-organizational development concept by managers. That is why boundaryless } \\
\text { careers become the background to accumulate and implement numerous skills and } \\
\text { habits garnered by knowledge workers. It has been analysed that imagination and } \\
\text { creativity, which are inherent traits of every new type worker, assure that } \\
\text { knowledge workers produce new knowledge-intensive products demanded in the } \\
\text { world market by a new type of consumers. }\end{array}$ \\
\hline
\end{tabular}

\section{ФОРМУВАННЯ РОБІТНИКА НОВОГО ТИПУ В ТЕОРІЇ ЕКОНОМІКИ ЗНАНЬ}

Осаул А.О.

Запорізький наиіонаьний університет

Украӥна, 69600, м. Запоріжжя, вул. Жуковського, бб

\section{Ключові слова:}

знання, нагромадження, нематеріальні ресурси, знаннєва економіка, робітники економіки знань, мережі знань, економіка навчання, робітники економіки навчання.
У статті проаналізовано концепцію нового типу працівників у межах парадигми економіки знань. Проілюстровано еволюцію теорії економіки знань у XXI столітті. Продемонстровано, що зміни, які відбулися в ставленні до роботи, а саме соціальних взаємодій, інноваційної інфраструктури, соціально-економічної, правової та інституційної складової, спричинили появу та подальший розвиток специфічного середовища для нового виду діяльності працівників. Узагальнено найбільш змістовні наукові праці зарубіжних науковців. Наголошено на нематеріальній сутності вирішальної продуктивної сили економічного суспільства, необхідності генерувати, накопичувати та поширювати знання суб'єктами за допомогою особистих контактів через мережі знань. Зроблено висновок, що існує низка характеристик, які відрізняють продуктивність працівника, що займається фізичною працею та продуктивність працівника економіки знань. Робітники економіки знань орієнтовані на виконання завдань, прагнуть до особистої відповідальності, самостійності, постійних інновацій, вважають себе найціннішим активом організації, беруть участь у навчанні і викладанні. Указано, що неможливо оцінити вплив працівників економіки знань на діяльність організації, застосовуючи лише кількісний підхід. Новий тип працівників, тобто професіонали, що вирішують проблеми, обирає новий тип гнучкої організації, керівництво якої готове до змін. Продемонстровано, що сучасні працівники переважно шукають тимчасової роботи та короткострокових контрактів, на що вказує сучасна статистика ринку праці. 
Виявлено, що так звана кар'єра без меж сприймається менеджерами як концепція міжорганізаційного розвитку. Вона стає основою для накопичення та впровадження навичок та вмінь, здобутих працівниками знань. Проаналізовано, що уява та креативність, які є рисами, притаманними кожному працівнику нового типу, сприяють створенню наукоємної продукції, попит на яку створює на світовому ринку новий тип споживачів.

\section{Statement of the problem}

The development of labour's nature in the $21^{\text {st }}$ century involves both the formation and development of a new type of worker, i.e. a worker of a post-industrial society. In our view, the concept of a new type of worker reflects the socio-economic type of individual because of the postindustrial transformation of production, which is fundamentally different from the worker of the industrial era and pre-industrial manual labourer. The labour development, the complexity of its nature, significance of creativity and universalization as the key requirements of the labour market all around the world form the basis of the formation of a number of universal features inherent for a new type of worker. Knowledge workers and learning workers are subjects of the modern knowledge economy. Their ability to learn, generate and accumulate knowledge is a key characteristic of economic performance. Recognizing them as the carriers of change in modern economic systems of any level proves the need to study their nature, development determinants, classification, including the differentiation of types of knowledge, ways of teaching by scholars. Currently, education itself makes the greatest contribution to the generation and accumulation of knowledge, which is an internal component of the well-being of economic agents.

\section{Analysis of recent studies and publications}

The concept of post-industrial society advocated by D. Bell [1], M. Castells [2], A. Toffler [3] and other scholars paid much attention to the intangible resources like knowledge and information, the shift of the centre of gravity in economic activity from production of goods to the production of services; the leading role of professions associated with high saturation of knowledge and information. P. Drucker $[4 ; 5]$ analysed knowledge workers, determinants of their development and the main characteristics of their activities. R. Reich [6] associated knowledge workers' activities and the new type of workers' development in the context of the existing corporate strategists. T. Davenport [8] not only implemented the activities of knowledge carriers in the work of an organization, but also compared the traits of workers in the industrial era and the era of knowledge dominance. The changes taking place in the world, socioeconomic systems' agility lead to changes in organizational systems, which gives rise to new approaches to the assessment of the environment in which knowledge carriers operate. Brown, J. S. and Duguid, P. [9] study knowledge workers' network structures, both at the corporate and regional levels. Bengt-äke Lundvall and Björn Johnson [10] point out the necessity to move to the concept of learning economy and learning workers as more complex and up-to-date that the knowledge economy theory.

\section{Objectives of the article}

The objective of this article is to identify the role of a new type of worker within the existing knowledge economy theory and further improve it within the learning economy.
In particular, the tasks were set to identify inherent characteristics of a new type of workers, to analyse reasons for their willingness to integrate into the knowledge networks at both micro- and meso-economic levels, as well as the impact of knowledge generation and accumulation on the well-being.

\section{The main material of the research}

Nowadays there is no single approach to the definition of a knowledge worker as well as of "knowledge work" category. These concepts, directly related to the knowledge economy operation, are its integral components. In addition, both are knowledge-based.

Peter Drucker was the first scholar to provide the concept of a "knowledge worker" in 1968 [5]. According to his research work: "Today the centre is the knowledge worker, the man or woman who applies to productive work ideas, concepts, and information rather than manual skill or brawn... Where the farmer was the backbone of any economy a century or two ago... knowledge is now the main cost, the main investment, and the main product of the advanced economy and the livelihood of the largest group in the population' [5, p. 264]. The basics of knowledge worker concepts is not physical capital, but an intangible resource like knowledge, the driving force of the globalized labour market. Knowledge workers cannot be satisfied by the work itself for the sake of livelihood. They see themselves as professionals or intellectuals. In other words, if knowledge workers prefer knowledge in general, then they also require professionalism and intellectual capital to become the background for their self-realization. Knowledge workers need completely different managerial approaches to build cooperation links with them. Challenges to knowledge workers should be put not by the management, but by knowledge, in other words, a new type of workers responds more effectively not to people, but to the correct goals. P. Drucker points out that "Knowledge, therefore, has to be organized as a team in what the task decides who is in charge, when, for what, and for how long" [5, p.289].

It should be noted that the conceptual definitions of knowledge work have been singled out by the scientists, as one that gives the individual more opportunities to pursue his or her beloved work.

P. Drucker emphasized the difference between manual worker productivity and knowledge worker productivity. Manual worker productivity was examined in detail according to Taylor's revolutionary approach. Knowledge worker productivity was specified in accordance with six determinants: firstly, knowledge workers should answer the question "What is the task?"; secondly, knowledge workers have personal responsible for their productivity, self-management at work, i.e. they are autonomous units; thirdly, continuous innovation is an integral part of knowledge workers' work, their mission and responsibility; fourthly, knowledge work requires both continuous training of knowledge workers and participation in the teaching process; fifthly, the 
productivity of a new type of worker is measured and analysed not only quantitatively, but also qualitatively; sixthly, productivity is based on the recognition of knowledge workers as a valuable asset of an organization, which, other things equal, has been favoured by these professionals [4, p.84]. Therefore, Drucker pushed the envelope of traditional work within the industrial economy. He outlined a modernized concept of productive work, where employees are given more responsibly.

R. Reich described specialized knowledge as the central category of modern corporations`strategies. Specialized knowledge is embodied in three major skill sets of a new type of workers, namely "problem-solving skills", "skills required to help customers understand their needs and how those needs can best be met by customized products", "skills needed to link problem-solvers and problemidentifiers" [7, p. 89]. Problem-solving professionals must have in-depth knowledge of various scientific fields of activity and have methods of converting theoretical knowledge to R\&D and manuals to produce products demanded by the globalized market. They are not mass production oriented, constantly seek for the new ways to apply the proposed ideas, combinations, and enhancements that can solve problems faced by an organization. Knowledge about the peculiarities of doing business and the competitive advantages form the work basis for professionals who identify new problems and opportunities of economic entities. Thus, the art of persuasion is substituted by the development of new business opportunities that are often associated with an individual product. The combination of roles to identify and solve problems goes beyond the standard notion of "executives" or "entrepreneurs" who perform standard management functions. In the framework of knowledge economy, experts are primarily involved in the process of producing ideas. They act as so-called strategic brokers. R. Reich calls them "symbolic analysts". The name refers to lawyers, bankers, researchers, consultants who deal with non-standard problem-solving, applying a set of analytical tools that are often abstract in nature. Their productivity and success in organizational work depend on their propensity for creativity and innovation. The economic sectors where they produce symbolic-analytic services are characterized by the transformation of business practices. As a result, professionals producing these types of services become more competitive than those providing "routine production services" and "inperson services". In general, according to R. Reich's estimates, these three categories of specialists stand for $75 \%$ of jobs in the USA, but the share of symbolic-analytic services is growing at the fastest rate.

T. Davenport like P. Drucker and R. Reich when studying knowledge management defines knowledge workers as those who "have high degrees of expertise, education, or experience, and the primary purpose of their jobs involves the creation, distribution, or application of knowledge" [8, p.10]. The researcher focused on the main differences between knowledge workers and other types of workers, ways of decision-making, and the peculiarities of knowledge workers`motivation. T. Davenport identified a number of key characteristics that are common to knowledge workers, such as: (1) autonomy; (2) the complexity of detailing the stages of knowledge-intensive activity and its process in comparison with other types of work, but also its relatively lower value; (3) greater determination that they have chosen the right career; (4) involvement in the work. As T. Davenport believed in the heterogeneity of work, its complexity and specific interaction of its performers, it gave him the opportunity to single out routine work, repetitive work, judgmentoriented work and improvisational work within the concept of knowledge work. Unlike P. Drucker, T. Davenport proposes to use the concepts of "performance" and "results" as the goals of quality knowledge work instead of the category of "productivity", because quality is a critical determinant of knowledge work. Understanding of knowledge work as a process assumes that workers are more likely to accept changes that occur in an organization and agree with them when they participate in the process of developing those changes, that is, they perceive management in all its manifestations as change management. The involvement of knowledge workers in all kinds of organizational changes has to be participative, incremental, and continuous.

Milton Correia de Sousa and Dirk van Dierendonck, as well as Robert N. Bellah, agree that knowledge workers in modern organizations perceive work as a source of implicit pleasure and self-realization, and work itself often serves as the goal of their activity. It is explained, first of all, by the peculiarities of a long period of study, which determines a well-considered decision concerning the study program and worker`s career aptitude; secondly, by the abstract nature of the activity, which contributes to the development of systemic thinking and, consequently, a better understanding of labour's impact and contribution to organizational performance in general; thirdly, knowledge workers are relatively more mobile, their choice is broader in comparison with other workers due to their contact within global networks [11, p.232].

The development of labour as a factor of production, its complexity, the growth of its creativity component, the universalization of labour, elimination of the gap between manual and knowledge labour form the basis of the formation of a number of universal features inherent to a new type of worker, i.e. development of new abilities and needs, formation of new type of labour consciousness, including new values and motivational attitudes. The most important feature of a new type of worker is a high level of creativity. By creativity, we mean a distinguished inclination towards creative work. Moreover, we consider that creativity is not identical to human intelligence. The process of creativity is embodied in creative activity, the result of which is the production of new material and spiritual values or new patterns and algorithms for creating these values. The process of creativity is impossible without certain traits, motives, knowledge, skills, which create a product characterized by novelty, originality and uniqueness. Besides, self-management, flexibility, the ability to learn quickly, communication skills and a constant willingness to complete tasks as essential elements of individualization are inherent to knowledge workers [12]. Creativity in the age of knowledge economy 
is recognized as a necessary resource that defines successful "boundaryless careers" opposed to the traditionalist vision of a career in an organization in the industrial era. Due to the decentralization of organizational activities, the transition to more flexible employment occurs and there are additional benefits for an enterprise thanks to new career opportunities for its employees [13, p.296]. Boundaryless careers as an interorganizational development concept provide an opportunity to accumulate and implement numerous skills and habits accumulated by knowledge workers. Firstly, the accumulation occurs at the level of individual properties`structure, which reflect employees' aggregate propensity, their experience and reputation in the process of career development. Secondly, this tendency impacts the organization's size, algorithm and ability to resist when it penetrates the organizational structure. Thus, when new ideas about the resources that form the basis of knowledge workers replace old and traditional approaches, the concepts of "boundaryless career" and "organizational career" coincide at the same microeconomic level. However, the emergence of a new type of workers and their recognition within the enterprise initiate further cooperation and competition between business entities within a new type of career behaviour. As a result, shifts in the internal organizational development concept disturb the overall structure of the knowledge economy.

The imagination and creativity guarantee that knowledge workers produce new knowledge-intensive products by the extraordinary combination of unrelated ideas, concepts, categories, data, information or knowledge and non-trivial analytical decisions [3, p. 218]. However, if organization aims at retaining competitive advantages over a long period it is not enough to administer the existing knowledge capital embodied in its workers, it is necessary to continuously generate new knowledge in order to produce new goods and services. Accumulation and further application of knowledge workers ' capacity is carried out through the "knowledge networks", which are the basis for their career behaviour implementation, provide access to other economic agents` knowledge resources. Individual networks of knowledge workers have the ability to be accumulate in social networks at the firm level and determine inter-firm dependencies and exchange relationships [14]. As a result, network relationships satisfy both individual agents' career interests and employer' strategic interests. Networks also act as platforms for learning affecting all players of socioeconomic relations. Lifelong learning multiplies worker's value and his/hers human capital. Moreover, learning within network communities through the "communities of practice" can have a dual effect as individuals learn and invest their knowledge in the working groups which they join in [9, p.49]. Today training is being embedded in enterprise training programs that, at best, enhance employees 'competencies and create motivation to transfer knowledge within the organization, and at worst, diminish workers' competencies and provoke unwillingness to participate in corporate training. Training has a wider impact at the regional level, as knowledge workers' networks form the background for new businesses and the expansion of existing ones, generating regional competitive advantages - knowledge, skills and competences - by their production, exchange, distribution and consumption within networks.

We believe that today it is relevant to talk not only about knowledge economies, but also about learning economies, for which technical and organizational changes are builtin variables. According to Bengt-äke Lundvall and Björn Johnson, institutionalization of the educational process and accumulation of knowledge are inherent in the economic system, including in the production and consumption phase of public production through "learning by doing" and "learning by using" [10]. In learning economies, organizational structures of enterprises are designed to increase learning skills, such as networking with other enterprises, horizontal communication patterns, staff flows between departments and positions. The enterprises become learning organizations that intensify their staff training and constantly transform themselves. Learning workers become more productive and efficient due to the involvement in innovation activity. In the era of high international specialization learning workers enter close cooperative relationships with colleagues, divisions, businesses, and sometimes with competing structures. The subjects of learning organizations are in cooperative relationships, both within the organization itself and with the external environment. Openness as a sign of modern world economy proves that formation and accumulation of knowledge and skills through co-operative learning is far more economically viable than isolation.

\section{Conclusions}

Human potential as the basis for the comprehensive development of organization is a modern manifestation of a new paradigm of human civilization evolution. Workers as the bearers of knowledge are the engine of progress, as well as the subject of the debate among scientists regarding changes in the nature of the work of a new type of workers within the framework of knowledge economy theory and industrial economy theory. Education and training, innovative infrastructure, current socioeconomic incentives, institutional foundations and active knowledge networks together form the environment at different economic levels for the dynamic development and improvement of new workers, accumulation and distribution of their intellectual capacity. However, the concepts of a new type of worker and knowledge economy as well are on the go. Nowadays, studies of learning economics and learning workers, including gig economy, as prospects for the development of the global labour market are relevant, as the latter is gradually creating an environment that supports and stimulates temporary employment, short-term projects and services. A new type of workers is developing traits that meet the challenges of the new environment, for instance deep learning. Thus, in the context of digitalization, workforce flexibility, Millennials` new attitude towards work, for example, to change it during life, the evolution of "traditional" employment concept and its impact on well-being is taking place. 


\section{References}

1. Bell, D. (1999). The Coming of Post-Industrial Society: A Venture in Social Forecasting. Basic Books. Retrieved from https://b-ok.cc/book/2330217/f8ab0b [in English].

2. Castells, M. (2010). End of Millennium: The Information Age: Economy, Society, and Culture Volume III (Information Age Series). Wiley-Blackwell. Retrieved from https://b-ok.cc/book/859921/0e056e [in English].

3. Toffler, A., Toffler, H. (2006). Revolutionary Wealth. Knopf. Retrieved from https://bok.cc/book/3509713/c20698 [in English].

4. Drucker, Peter F. (1999). Knowledge-Worker Productivity: The Biggest Challenge. California management review, Vol.41, No.2. Retrieved from http://forschungsnetzwerk.at/downloadpub/knowledge_workers_the_bigge st_challenge.pdf [in English].

5. Drucker, Peter F. (1992). The Age of Discontinuity: Guidelines to Our Changing Society. Harper \& Row. Retrieved from https://b-ok.cc/book/1120334/7ea354 [in English].

6. Reich Robert B. (1992). The work of nations. New York: Vintage Books. Retrieved from https://bok.cc/book/3582109/00b975 [in English].

7. Brogan, M. L. (1992). Review of Robert B. Reich, The Work of Nations: Preparing Ourselves for 21st Century Capitalism. Retrieved from http://repository.upenn.edu/library_papers/36 [in English].

8. Davenport Thomas H. (2005). Thinking for a Living How to Get Better Performance and Results from Knowledge Workers. Boston, Massachusetts: Harvard Business School Press. Retrieved from https://www.researchgate.net/publication/248078273_Thinking_for_A_Living_How_to_Get_Better_Performanc e_and_Results_from_Knowledge_Workers [in English].

9. Brown, J.S., Duguid, P. (1991). Organizational Learning and Communities-of-Practice: Toward a Unified View of Working, Learning, and Innovation. Special Issue: Organizational Learning: Papers in Honor of (and by) James G., Vol. 2, No. 1 Books Retrieved from https://pdfs.semanticscholar.org/92f9/30c82c44515622 cc04819ae2f1cdfb2746ca.pdf?_ga=2.247470798.87929848.1583690470-925846657. 1583690470 [in English].

10. Lundvall, Bengt-äke, Johnson, B. (1994). The Learning Economy. Journal of Industry Studies, 2, 23-42 [in English]

11. Correia de Sousa, M., van Dierendonck, D. (2010). Knowledge workers, servant leadership and the search for meaning in knowledge-driven organizations. On the Horizon, 3, 230-239 [in English]

12. Murgia, A., Armano, E., Maestripieri, L. (2017). Special issue The Precariousness of Knowledge Workers (part 2). Work Organisation, Labour and Globalisation. Retrieved from https://www.researchgate.net/publication/317352695_The_Precariousness_of_Knowledge_Workers_part_2_for ms_and_critiques_of_autonomy_and_self-representation /link/59414e3e-0f7e9bd3a9a5edc6/download [in English]

13. Arthu,r M.B., Rousseau, D.M. (2001). The Boundaryless Career: A New Employment Principle for a New Organizational Era. Oxford University Press USA [in English]

14. Burt, R.S. (2000). The Network Structure of Social Capital. Research in Organizational Behavior, 22, $345-423$ [in English] 